\title{
Estradiol and resveratrol stimulating effect on osteocalcin, but not osteonectin and collagen-1 $\alpha$ gene expression in primary culture of rat calvarial osteoblast-like cells
}

\author{
MARCIN RUCINSKI ${ }^{1}$, AGNIESZKA ZIOLKOWSKA ${ }^{1}$, ANNA HOCHOL ${ }^{1}$, ANDRZEJ PUCHER ${ }^{2}$, \\ CARLO MACCHI ${ }^{3}$, ANNA S. BELLONI ${ }^{3}$, GASTONE G. NUSSDORFER ${ }^{3}$ and LUDWIK K. MALENDOWICZ ${ }^{1}$ \\ Departments of ${ }^{1}$ Histology and Embryology; and ${ }^{2}$ Orthopedy and Traumatology, \\ Poznan University of Medical Sciences, PL-60781 Poznan, Poland; ${ }^{3}$ Department of Human \\ Anatomy and Physiology, Section of Anatomy, University of Padua, I-35121 Padua, Italy
}

Received April 7, 2006; Accepted June 3, 2006

\begin{abstract}
Evidence is available that some endocrine disruptors, acting as selective estrogen receptor modulators (SERMs), interfere with osteoblast differentiation and function. Therefore, we investigated whether 17ß-estradiol, bisphenol-A (BSP), silymarin, genistein, resveratrol, procymidone, linurone and benzophenone-3 (BP3) modulate differentiation of rat calvarial osteoblast-like (ROB) cells in primary in vitro culture. Disruptors were added at day 18 of culture and cells were harvested $48 \mathrm{~h}$ later. Real time-PCR revealed that estradiol and resveratrol enhanced osteocalcin mRNA expression in ROB cells, while other disruptors were ineffective. The expression of osteonectin and collagen- $1 \alpha$ was not affected by any disruptor. Estradiol, resveratrol, genistein and BSP stimulated the proliferative activity of ROB cells. In contrast, procymidone and linurone inhibited the proliferative activity, and silymarin and BP3 were ineffective. The conclusion is drawn that i) only resveratrol is able, like estradiol, to stimulate the specialized functions of ROB cells, and ii) the proliferative activity of ROB cells is more sensitive to endocrine disruptors, some of which could probably act via a mechanism independent of their SERM activity.
\end{abstract}

\section{Introduction}

Endocrine disruptors are both naturally occurring and synthetic chemical substances that exert adverse effects on an organism or its progeny acting through the endocrine system (1). The best recognized endocrine disrupting properties of chemicals

Correspondence to: Professor G.G. Nussdorfer, Department of Human Anatomy and Physiology, Section of Anatomy, Via Gabelli 65, I-35121, Padua, Italy

E-mail: gastone.nusdorfer@unipd.it

Key words: rat calvarial osteoblast-like cells, 17ß-estradiol, resveratrol, endocrine disruptors, osteocalcin, osteonectin, collagen$1 \alpha$, proliferative activity are those connected with their estrogenic activities, and several disruptors act as selective estrogen receptor (ER) modulators (SERMs) (1-3).

The presence of ERs in osteoblasts is well documented. Estrogens are known to affect differentiation and function of osteoblasts, including their proliferative activity (4-8). However, the results of studies dealing with the effects of SERMs on osteoblasts are rather conflicting, probably because estrogens act on osteoblasts not only directly, but also indirectly via their interaction with other cell types $(6,9,10)$.

One of the most useful in vitro models for investigating the specific gene events associated with osteoblast proliferation, differentiation and mineralization of extracellular matrix is the primary culture of rat calvarial osteoblast-like (ROB) cells (11-18). ROB cells in primary culture spontaneously differentiate into osteoblasts, and this process is associated with the increased expression of both collagen and noncollagenous bone proteins, including osteocalcin, osteopontin and osteonectin $(11,19,20)$.

The aim of the present study was to examine the direct effects of estradiol and several SERMs on the level of expression of collagen- $1 \alpha$, osteonectin and osteocalcin genes and the proliferative activity of ROB cells in primary culture.

\section{Materials and methods}

Animals and reagents. Two-day-old Wistar rats, born in our laboratory facilities, were used, and the study protocol was approved by the local Ethics Committee for Animal Studies. Diphenylolpropane (bisphenol-A; BSP), benzophenone-3 (Eusolex-4360; BP3) and 17ß-estradiol were purchased from Merck \& Co. (Whitehouse Station, NJ). Resveratrol was obtained from Nabio Biotech Co. (Shanghai, China). Other endocrine disruptors (genistein, procymidone, linurone and silymarin), Dulbecco's modified Eagle's medium (DMEM), fetal calf serum (FCS) and all other reagents were provided by Sigma-Aldrich Corp. (St. Louis, MO).

Primary $R O B$ cell culture. The technique used was described by Boden et al (13) with few modifications. Briefly, calvarias of 8 rats were immediately placed in DMEM, and the 
Table I. PCR primers and PCR products.

\begin{tabular}{|c|c|c|c|}
\hline Primer & Sequence (5'-3') & Product size (bp) & Accession number \\
\hline \multicolumn{4}{|l|}{ Osteocalcin } \\
\hline Sense (328-347) & CAAAGCCCAGCGACTCTG & & \\
\hline Antisense (117-134) & AAACGGTGGTGCCATAGATG & 231 & NM013414 \\
\hline \multicolumn{4}{|l|}{ Osteonectin } \\
\hline Sense (646-666) & CTGCCACTTCTTTGCGACCA & & \\
\hline Antisense (411-430) & CTCCAGGCGCTTCTCGTTCTC & 256 & NM012656 \\
\hline \multicolumn{4}{|l|}{ Collagen- $1 \alpha$} \\
\hline Sense (3271-3292) & CAAGCTGACAGAGGCATAAAGG & & \\
\hline Antisense (3425-3444) & AGGGAGACCGTTGAGTCCAT & 174 & Z78279 \\
\hline \multicolumn{4}{|l|}{ GAPDH } \\
\hline Sense (18-37) & TTCTAGAGACAGCCGCATCT & & \\
\hline Antisense (104-123) & TGGTAACCAGGTGTCCGATA & 106 & X02231 \\
\hline
\end{tabular}

connective tissue was removed. Calvarias were cut into small fragments that were dissociated to cell suspensions by enzymatic digestion with $0.1 \%$ collagenase-I for $30 \mathrm{~min}$ at $37^{\circ} \mathrm{C}$. ROB cells were harvested by centrifugation and resuspended in DMEM supplemented with $\mathrm{NaHCO}_{3}, 6 \%$ FCS and antibiotic-antimycotic solution. Cells were then plated in culture dishes $\left(10^{4}\right.$ cells/dish $)$, and cultured for 20 days at $37^{\circ} \mathrm{C}$ in a humidified atmosphere of $95 \%$ air- $5 \% \mathrm{CO}_{2}$, medium being changed every $24 \mathrm{~h}$.

Incubation with SERMs. Two days before exposure to SERMs, ROB cells were cultured in DMEM deprived of FCS. SERMs were dissolved in ethanol or DMEM and added to the cultures (at concentrations from $10^{-12}$ to $10^{-6} \mathrm{M}$ ) at day 18 , and cells were harvested $48 \mathrm{~h}$ later. Final concentrations of solvent were as follows: BSP, $0.001 \%$ ethanol; resveratrol, $0.01 \%$ ethanol; silymarin and BP3, $0.1 \%$ ethanol; and estradiol and other SERMs, $0.01 \%$ DMSO. The same concentrations of solvent were added to the appropriate control cultures.

Real time-polymerase chain reaction $(P C R)$. Total RNA was extracted from ROB cells, as previously detailed $(21,22)$, and contaminating DNA was eliminated by DNase-I treatment (RNase-free DNase set; Promega, Madison, WI). The amount of total RNA was determined (23), and reverse transcription was performed using AMV reverse transcriptase (Promega) with oligo dT (PE Biosystems, Warrington, UK) as primers. Real-time PCR was carried out in a Roche Light-Cycler 2.0 with software version $4.0(24,25)$, using the primers shown in Table I. Briefly, reactions were performed in $20 \mu 1$ final volume solution, containing $4 \mu 1$ template cDNA, $0.5 \mu \mathrm{M}$ specific primers, $3.5 \mu \mathrm{M} \mathrm{MgCl}_{2}$ and $12.5 \mu \mathrm{l}$ Light-Cycler Fast Start DNA Master SYBR-Green-I mix (Roche Molecular Biochemicals, Mannheim, Germany). The following PCR program was used: denaturation step $\left(95^{\circ} \mathrm{C}\right.$ for $\left.10 \mathrm{~min}\right)$, and 45 cycles of three-steps of amplification (denaturation, $95^{\circ} \mathrm{C}$ for $10 \mathrm{sec}$; annealing, $58^{\circ} \mathrm{C}$ for $5 \mathrm{sec}$; and extension, $72^{\circ} \mathrm{C}$ for $10 \mathrm{sec})$. Subsequently, a melting curve $\left(60-90^{\circ} \mathrm{C}\right.$ with a heating

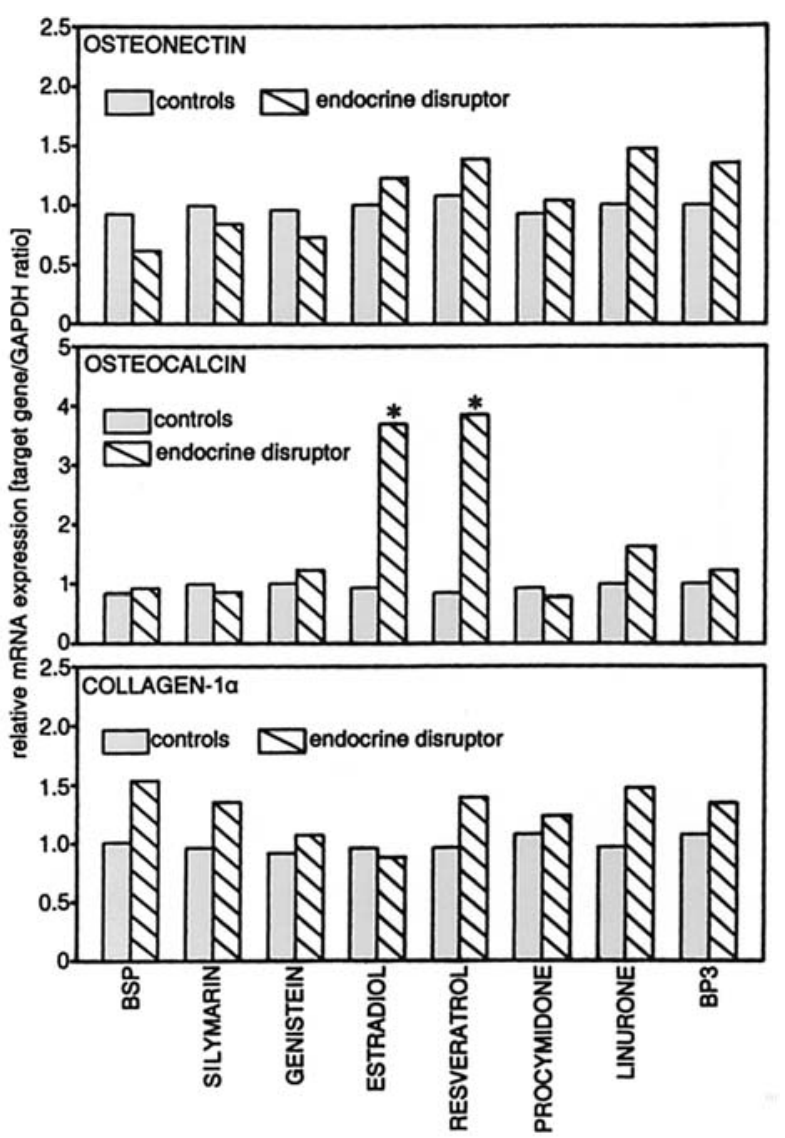

Figure 1. Effects of endocrine disruptors on osteonectin, osteocalcin and collagen- $1 \alpha$ gene expression in ROB cells in primary in vitro culture. Bars are means of three independent experiments. ${ }^{*} \mathrm{P}<0.05$ from controls.

rate of $0.1^{\circ} \mathrm{C} / \mathrm{sec}$ ) was carried out to check the specificity of amplification and the presence of byproducts. All samples were amplified in duplicate, and glyceraldehyde-3-phosphate dehydrogenase (GAPDH) was used as a reference to normalize data. 


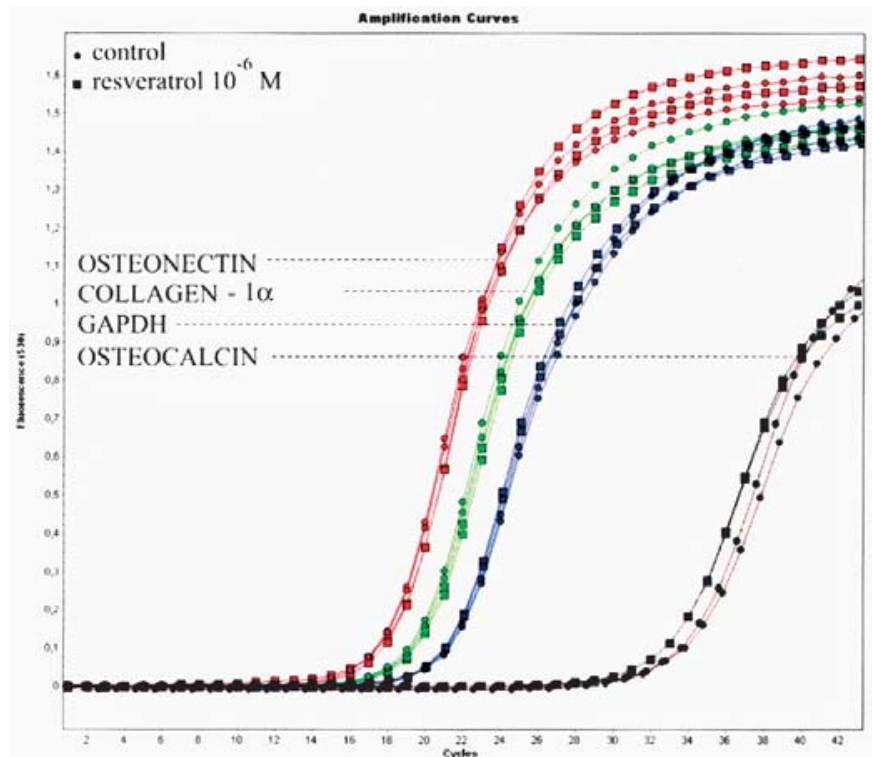

Figure 2. Exemplary results of real-time PCR amplification curves of osteonectin, osteocalcin, collagen-1 $\alpha$ and GAPDH from control and resveratrol-treated ROB cells in primary in vitro culture.

Cell proliferation. The proliferation rate of ROB cells was measured by the EZ4U nonradioactive cell proliferation and cytotoxic assay (Biomedica, Wien, Austria) $(26,27)$. In this assay, cultured cells were incubated for 90 min with EZ4U, and formazan production, which is linearly related to the cell number, was measured at $490 \mathrm{~nm}$ wavelength in a microplate autoreader (EL-13; Bio-Tek Instruments, Winooski, VT).

Statistics. Data were expressed as means \pm SEM of 3 or 5 independent experiments, and their statistical comparison was made by the unpaired Student's t-test.

\section{Results}

Real-time PCR showed that neither estradiol nor other SERMs altered collagen-1 $\alpha$ and osteonectin gene expression in ROB cells. In contrast, estradiol and resveratrol increased osteocalcin mRNA, while other disruptors were ineffective (Fig. 1). Exemplary amplification curves of appropriate cDNA obtained from control and resveratrol exposed ROB cells are shown in Fig. 2.

EZ4U assay showed that BSP $\left(10^{-12}\right.$ and $\left.10^{-6} \mathrm{M}\right)$, genistein $\left(10^{-8}\right.$ and $\left.10^{-6} \mathrm{M}\right)$, and estradiol and resveratrol $\left(10^{-10} \mathrm{M}\right)$ enhanced the proliferative activity of ROB cells. Silymarin and BP3 were ineffective, while procymidone $\left(10^{-6} \mathrm{M}\right)$ and linurone (from $10^{-10}$ to $10^{-6} \mathrm{M}$ ) significantly decreased the proliferative activity of cultured ROB cells (Fig. 3).

\section{Discussion}

The multifactorial regulation of bone formation and resorption is very sensitive to estrogens and endocrine disruptors but, as pointed out in the Introduction, rather controversial findings have been reported. It is well established that the primary action of estrogens on bone metabolism is related to their indirect effects on osteoclasts: the anti-resorptive action of

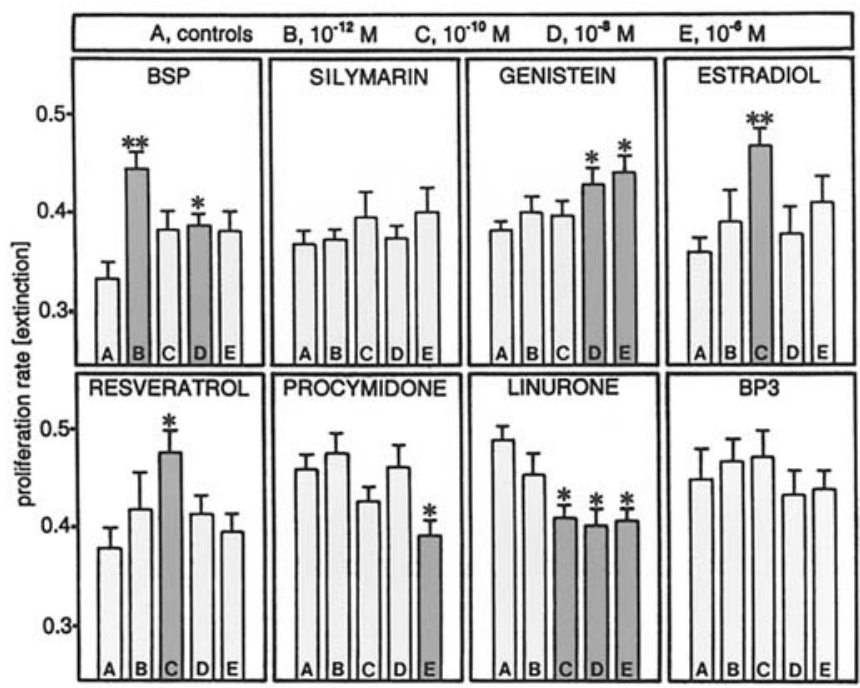

Figure 3. Effects of endocrine disruptors on the proliferative activity of ROB cells in primary in vitro culture. Bars are means \pm SEM of five independent experiments. ${ }^{*} \mathrm{P}<0.05$ and ${ }^{* *} \mathrm{P}<0.01$ from controls.

estrogens is thought to be mediated by their modulating effect on the release from osteoblastic lineage of paracrine factors that act on the osteoclasts $(6,28-30)$. Osteoblasts are known to express two functionally active ER isoforms, ER $\alpha$ and ERß. In primary cultures of ROB cells, the expression of ERß is rather constant throughout osteoblast differentiation, while the $\mathrm{ER} \alpha$ level increases during matrix maturation and then declines during mineralization (31). Our present study shows a clearcut stimulating effect of estradiol on osteocalcin, but not osteonectin and collagen- $1 \alpha$ expression in ROB cells, thereby confirming earlier observations (6). However, using the same experimental model, Chen et al $(32,33)$ were unable to evidence any effect of estradiol on osteocalcin gene expression. These discrepancies may be explained by taking into account the temporal sequence of expression of bone proteins in ROB cells: type I collagen and alkaline phosphatase are expressed early during the commitment to the osteoblastic phenotype, whereas osteopontin and osteocalcin are expressed later during osteoblastic differentiation (34-36). Hence, it may be reasonable to conceive that different results can be obtained depending on the stage of ROB cell culture. Estradiol $\left(10^{-10} \mathrm{M}\right)$ was also presently found to enhance the proliferative activity of ROB cells, an effect already observed in different models of osteoblastic cell culture $(4-6,28,29,37)$.

Among the various endocrine disruptors examined, resveratrol is the most frequently studied. Resveratrol, a phytoalexin found in red wine, belongs to the family of phytoestrogens, which are structurally similar to the synthetic estrogen diethylstilbestrol and exihibit selective SERM activity $(38-41)$. As far as bone is concerned, resveratrol was found to prevent dioxin-induced inhibition of collagen type I, osteopontin, bone sialoprotein and alkaline phosphatase synthesis (42). Moreover, in human bone marrow-derived mesenchymal stem cells, resveratrol has been reported to concentrationdependently enhance osteocalcin and osteopontin gene expression (43). On these grounds, it is not surprising that resveratrol exerts estradiol-like effects on ROB cells in primary 
culture: i.e. stimulation of osteocalcin gene expression and proliferative activity. Of interest, resveratrol has been shown to stimulate apoptosis in other cell systems, such as human breast cancer cells xenografted in nude mice (44).

The soy isoflavone genistein has structural characteristics similar to those of $17 ß$-estradiol $(40,45,46)$, which enables it to exert estrogenic and antiestrogenic actions. It should be underlined that isoflavones can also exert biological effects independent of their phytoestrogenic activity $(47,48)$, inasmuch as genistein acts as a potent inhibitor of tyrosine kinase $(49,50)$, an enzyme which is known to play a key role in the activation of MAPK cascade $(51,52)$. Available data suggest that diets rich in phytoestrogens have bone-sparing anabolic effects, although their mechanism(s) of action on the bone cells are largely unknown (53). In human cultured osteoblasts, genistein exerts a weak 17ß-estradiol-like effect via both ER $\alpha$ and ERß (7), and in the osteoblastic MC3T3 cell line it inhibits interleukin-6 production and enhances osteoprotegerin mRNA expression (33). Moreover, in cultured ROB cells genistein was found to raise osteocalcin release (54). Despite this last finding, we were unable to show any effect of this phytoestrogen on osteocalcin mRNA expression in ROB cells, which may again stress that the effects of SERMs on these cells do vary in relation to the stage of their in vitro culture. However, genistein, like estrogen and resveratrol, stimulates the proliferative activity of cultured ROB cells, an effect already observed in mouse bone marrow-derived mesenchymal stem cell cultures (55).

Like genistein, none of the other endocrine disruptors tested affect the expression of osteoblast marker genes in cultured ROB cells. However, some of them are able to variously modulate the proliferative activity of ROB cells. Briefly, BSP exerts estrogenic activity in some organs and tissue (5659), but when orally administered has no effect on either bone mineral density and osteocalcin level in rats or osteocalcin and osteopontin secretion from cultured osteoblasts $(58,61)$. In the present study, BSP was found to exert a strong proliferogenic action on ROB cells. BP3, commonly used in cosmetics and plastics, displays some structural relationships with steroid hormones (62), and has been reported to exert variable uterotrophic effects (63). Despite the fact that BP3 was found to enhance the proliferative activity of the MCF-7 breast cancer-derived cell line (64), it did not alter the proliferation rate of cultured ROB cells. The plant flavonoid silymarin (65), although exerting estrogen-like effects restricted to the metaphysis of the femur of ovariectomized rats (66), was unable to change the proliferative activity of cultured ROB cells. Procymidone and linurone are commonly used pesticides, possessing SERM activity $(59,67)$ and reported to exert different effects on sex hormone-target organs and tissues $(59,67-71)$. We observed a strong anti-proliferogenic action of both of these disruptors on cultured ROB cells.

In light of the present findings, we conclude that i) of the endocrine disruptors tested only resveratrol is able, like estradiol, to enhance the expression of osteocalcin in cultured ROB cells; and ii) in contrast with specialized osteoblast functions, ROB-cell proliferative activity is very sensitive to endocrine disruptors, some of which (procymidone and linurone) probably act via a mechanism independent of their SERM activity.

\section{Acknowledgements}

This study was supported by the European Community grant EURISKED (EVK1-CT 2002-00128).

\section{References}

1. Pombo $\mathrm{M}$ and Castro-Feijòo L: Endocrine disruptors. J Pediat Endocrinol Metab 18: 1145-1155, 2005.

2. Amaral-Mendes JJ: The endocrine disruptors: a major medical challenge. Food Chem Toxicol 40: 781-788, 2002.

3. Harvey PW and Everett DJ: The adrenal cortex and steroidogenesis as cellular and molecular targets for toxicity: critical omissions from regulatory endocrine disrupter screening strategies for human health? J Appl Toxicol 23: 81-87, 2003.

4. Ernst M, Heath JK and Rodan GA: Estradiol effects on proliferation, messenger ribonucleic acid for collagen and insulin-like growth factor-I, and parathyroid hormone-stimulated adenylate cyclase activity in osteoblastic cells from calvariae and long bones. Endocrinology 125: 825-833, 1989.

5. Ernst M, Heath JK, Schmid C, Froesch RE and Rodan GA: Evidence for a direct effect of estrogen on bone cells in vitro. $\mathrm{J}$ Steroid Biochem 34: 279-284, 1989.

6. Qu Q, Perala-Heape M, Kapanen A, Dahlund J, Salo J, Vaananen HK and Harkonen P: Estrogen enhances differentiation of osteoblasts in mouse bone marrow culture. Bone 22: 201-209, 1998.

7. Rickard DJ, Monroe DG, Ruesink TJ, Khosla S, Riggs BL and Spelsberg TC: Phytoestrogen genistein acts as an estrogen agonist on human osteoblastic cells through estrogen receptors alpha and beta. J Cell Biochem 89: 633-646, 2003.

8. Syed F and Khosla S: Mechanisms of sex steroid effects on bone. Biochem Biophys Res Commun 328: 688-696, 2005.

9. Bord S, Frith E, Ireland DC, Scott MA, Craig JL and Compston JE: Megakaryocytes modulate osteoblast synthesis of type-I collagen, osteoprotegerin and RANKL. Bone 36: 812-819, 2005.

10. Yamashita A, Takada T, Narita J, Yamamoto G and Torii R: Osteoblastic differentiation of monkey embryonic stem cells in vitro. Cloning Stem Cells 7: 232-237, 2005.

11. Aubin JE, Liu F, Malaval L and Gupta AK: Osteoblast and chondroblast differentiation. Bone 17 (suppl 2): 77S-83S, 1995.

12. Mundy GR: Local control of bone formation by osteoblasts. Clin Orthop Relat Res 313: 19-26, 1995.

13. Boden SC, McCuaig K, Hair G, Racine M, Titus L, Wozney JM and Nanes MS: Differential effects and glucocorticoid potentiation of bone morphogenetic protein action during rat osteoblast differentiation in vitro. Endocrinology 137: 3401-3407, 1996.

14. Hinoi E, Fujimori S, Nakamura Y and Yoneda Y: Group III metabotropic glutamate receptors in rat cultured calvarial osteoblasts. Biochem Biophys Res Commun 281: 341-346, 2001.

15. Bodine PV and Komm BS: Tissue culture models for studies of hormone and vitamin action in bone cells. Vitam Horm 65: 101-151, 2002.

16. Hinoi E, Fujimori S, Takemori A and Yoneda Y: Cell death by pyruvate deficiency in proliferative cultured calvarial osteoblasts. Biochem Biophys Res Commun 294: 1177-1183, 2002.

17. Kartsogiannis V and $\mathrm{Ng} \mathrm{KW:} \mathrm{Cell} \mathrm{lines} \mathrm{and} \mathrm{primary} \mathrm{cell} \mathrm{cultures}$ in the study of bone cell biology. Mol Cell Endocrinol 228: 79-102, 2004.

18. Tsukamoto $\mathrm{Y}$, Ishihara $\mathrm{Y}$, Miyagawa-Tomita S and Hagiwara H: Inhibition of ossification in vivo and differentiation of osteoblasts in vitro by tributyltin. Biochem Pharmacol 68: 739-746, 2004.

19. Hauschka PV, Lian JB, Cole DEC and Gundberg CM: Osteocalcin and matrix Gla protein: vitamin K-dependent proteins in bone. Physiol Rev 69: 990-1047, 1989.

20. Plant A and Tobias JH: Characterization of the temporal sequence of osteoblast gene expression during estrogen-induced osteogenesis in female mice. J Cell Biochem 82: 683-691, 2001.

21. Albertin G, Carraro G, Petrelli L, Guidolin D, Neri G and Nussdorfer GG: Endothelin-1 and adrenomedullin enhance the growth of human adrenocortical carcinoma-derived SW-13 cell line by stimulating proliferation and inhibiting apoptosis. Int $\mathbf{J}$ Mol Med 15: 469-474, 2005.

22. Albertin G, Carraro G and Nussdorfer GG: Human adrenomedullin gene silencing by short interfering RNAs: a preliminary study. Int J Mol Med 15: 579-583, 2005. 
23. Rucinski M, Andreis PG, Ziolkowska A, Nussdorfer GG and Malendowicz LK: Differential expression and function of beacon in the rat adrenal cortex and medulla. Int J Mol Med 16: 35-40, 2005.

24. Carraro G, Albertin G, Aragona F, Forneris M, Casale V, Spinazzi R and Nussdorfer GG: Age-dependent decrease in the ghrelin gene expression in the human adrenal cortex: A real time PCR study. Int J Mol Med 17: 319-321, 2006.

25. Spinazzi R, Petrelli L, Guidolin D, Carraro G, Casale V, Tortorella C, Neri G, Albertin G, Andreis PG, and Nussdorfer GG: In vitro culture on Matrigel favors the long-term maintenance of rat zona glomerulosa-cell differentiated phenotype. Int $\mathrm{J} \mathrm{Mol}$ Med 17: 1101-1110, 2006.

26. Hochol A, Albertin G, Nussdorfer GG, Spinazzi R, Ziolkowska A, Rucinski M and Malendowicz LK: Effects of neuropeptides B and $\mathrm{W}$ on the secretion and growth of rat adrenocortical cells. Int J Mol Med 14: 843-847, 2004.

27. Malendowicz LK, Spinazzi R, Tortorella C, Nussdorfer GG, Ziolkowska A and Rucinski M: Effects of leptin and leptin fragments on corticosterone secretion and growth of cultured rat adrenocortical cells. Int J Mol Med 14: 873-877, 2004.

28. Scheven BS, Damen CA, Hamilton NJ, Verhaar HJ and Duursma SA: Stimulatory effects of estrogen and progesterone on proliferation and differentiation of normal human osteoblastlike cells in vitro. Biochem Biophys Res Commun 186: 54-60, 1992.

29. Chen XW, Garner SC and Anderson JJ: Isoflavones regulate interleukin-6 and osteoprotegerin synthesis during osteoblast cell differentiation via an estrogen receptor-dependent pathway. Biochem Biophys Res Commun 295: 417-422, 2002.

30. Viereck V, Grundker C, Blaschke S, Siggelkow H, Emons G and Hofbauer LC: Phytoestrogen genistein stimulates the production of osteoprotegerin by human trabecular osteoblasts. J Cell Biochem 84: 725-735, 2002.

31. Wiren KM, Chapman-Evans A and Zhang XW: Osteoblast differentiation influences androgen and estrogen receptor-alpha and -beta expression. J Endocrinol 175: 683-694, 2002.

32. Chen L, Zeng T, Xia W and Ke L: Comparison on the effects of three sex hormones on the fetal rat calvarial osteoblasts. J Tongii Med Univ 20: 59-62, 2000.

33. Chen X, Garner SC, Quarles LD and Anderson JJ: Effects of genistein on expression of bone markers during MC3T3-E1 osteoblastic cell differentiation. J Nutr Biochem 14: 342-349, 2003.

34. Rodan GA and Noda M: Gene expression in osteoblastic cells. Crit Rev Eukaryot Gene Expr 1: 85-98, 1991.

35. Majeska RJ, Ryaby JT and Einhorn TA: Direct modulation of osteoblastic activity with estrogen. J Bone Joint Surg Am 76: 713-721, 1994.

36. Waters KM, Rickard DJ, Riggs BL, Khosla S, Katzenellenbogen JA, Katzenellenbogen BS, Moore J and Spelsberg TC: Estrogen regulation of human osteoblast function is determined by the stage of differentiation and the estrogen receptor isoform. J Cell Biochem 83: 448-462, 2001

37. Kaye AM, Weisman Y, Harell A and Somjen D: Hormonal stimulation of bone cell proliferation. J Steroid Biochem Mol Biol 37: 431-435, 1990.

38. Gehm BD, McAndrews JM, Chien PY and Jameson JL: Resveratrol, a polyphenolic compound found in grapes and wine, is an agonist for the estrogen receptor. Proc Natl Acad Sci USA 94: 14138-14143, 1997.

39. Bowers JL, Tyulmenkov VV, Jernigan SC and Klinge CM: Resveratrol acts as a mixed agonist/antagonist for estrogen receptors alpha and beta. Endocrinology 141: 3657-3667, 2000.

40. Cos P, De Bruyne T, Apers S, Van den Berghe D, Pieters L and Vlietinck AJ: Phytoestrogens: recent developments. Planta Med 69: 589-599, 2003

41. Granados-Soto V: Pleiotropic effects of resveratrol. Drug News Perspect 16: 299-307, 2003.

42. Singh SU, Casper RF, Fritz PC, Sukhu B, Ganss B, Girard B Jr, Savouret JF and Tenenbaum HC: Inhibition of dioxin effects on bone formation in vitro by a newly described aryl hydrocarbon receptor antagonist, resveratrol. J Endocrinol 167: 183-195, 2000.

43. Boissy P, Andersen TL, Abdallah BM, Kassem M, Plesner T and Delaisse JM: Resveratrol inhibits myeloma cell growth, prevents osteoclast formation, and promotes osteoblast differentiation. Cancer Res 65: 9943-9952, 2005.

44. Garvin S, Ollinger K and Dabrosin C: Resveratrol induces apoptosis and inhibits angiogenesis in human breast cancer xenografts in vivo. Cancer Lett 231: 113-122, 2006.
45. Yang J, Nakagawa $H$, Tsuta $K$ and Tsubura $A$ : Influence of perinatal genistein exposure on the development of MNUinduced mammary carcinoma in female Sprague-Dawley rats. Cancer Lett 149: 171-179, 2000.

46. Lephart ED, Setchell KD, Handa RJ and Lund TD: Behavioral effects of endocrine-disrupting substances: phytoestrogens. ILAR J 45: 443-454, 2004.

47. Valachovicova T, Slivova V and Sliva D: Cellular physiological effects of soy flavonoids. Mini Rev Med Chem 4: 881-887, 2004.

48. Malendowicz LK, Trejter M, Rebuffat P, Ziolkowska A, Nussdorfer GG and Majchrzak M: Effects of some endocrine disruptors on the secretory and proliferative activity of the regenerating rat adrenal cortex. Int J Mol Med 18: 197-200, 2006.

49. Akiyama T, Ishida J, Nakagawa S, Ogawara H, Watanabe S, Itoh N, Shibuya M and Fukami Y: Genistein a specific inhibitor of tyrosine-specific protein kinases. J Biol Chem 262: 5592-5595, 1987.

50. Dhar A, Paul AK and Shukla SD: Platelet-activating factor stimulation of tyrosine kinase and its relationship to phospholipase $\mathrm{C}$ in rabbit platelets: studies with genistein and monoclonal antibody to phosphotyrosine. Mol Pharmacol 37: 519-525, 1990.

51. Fanger GR: Regulation of the MAPK family members: role of subcellular localization and architectural organization. Histol Histopathol 14: 887-894, 1999.

52. Baiguera S, Conconi MT, Guidolin D, Mazzocchi G, Malendowicz LK, Parnigotto PP, Spinazzi R and Nussdorfer GG: Ghrelin inhibits in vitro angiogenic activity of rat brain microvascular endothelial cells. Int J Mol Med 14: 849-854, 2004.

53. Setchell KD and Lydeking-Olsen E: Dietary phytoestrogens and their effect on bone: evidence from in vitro and in vivo human observational and dietary intervention studies. Am J Clin Nutr 78 (suppl 3): 593S-609S, 2003.

54. Chang H, Jin TY, Jin WF, Gu SZ and Zhou YF: Modulation of isoflavones on bone-nodule formation in rat calvaria osteoblasts in vitro. Biomed Environ Sci 16: 83-89, 2003.

55. Pan W, Quarles LD, Song LH, Yu YH, Jiao C, Tang HB, Jiang CH, Deng HW, Li YJ, Zhou HH and Xiao ZS: Genistein stimulates the osteoblastic differentiation via NO/cGMP in bone marrow culture. J Cell Biochem 94: 307-316, 2005

56. Hirose A, Koizumi M and Hasegawa R: Bisphenol alkylphenols. Nippon Rinsho 58: 2428-2433, 2000.

57. Ashby $\mathrm{J}$ : Increasing the sensitivity of the rodent uterotrophic assay to estrogens, with particular reference to bisphenol A. Environ Health Perspect 109: 1091-1094, 2001.

58. Seidlova-Wuttke D, Jarry $H$ and Wuttke W: Pure estrogenic effect of benzophenone-2 (BP2) but not of bisphenol A (BPA) and dibutylphtalate (DBP) in uterus, vagina and bone. Toxicology 205: 103-112, 2004

59. Seidlova-Wuttke D, Jarry H, Christoffel J, Rimoldi G and Wuttke W: Effects of bisphenol-A (BPA), dibutylphtalate (DBP), benzophenone-2 (BP2), procymidone (Proc), and linurone (Lin) on fat tissue, a variety of hormone and metabolic parameters: a 3 month comparison with effects of estradiol (E2) in ovariectomized (ovx) rats. Toxicology 213: 13-24, 2005.

60. Dodge JA, Glasebrook AL, Magee DE, Phillips DL, Sato M, Short LL and Bryant HU: Environmental estrogens: effects on cholesterol lowering and bone in the ovariectomized rat. J Steroid Biochem Mol Biol 59: 155-161, 1996.

61. Toda K, Miyaura C, Okada T and Shizuta Y: Dietary bisphenol-A prevents ovarian degeneration and bone loss in female mice lacking the aromatase gene (CYP19). Eur J Biochem 269: 2214-2222, 2002.

62. Gustavsson-Gonzales H, Farbrot A and Larko O: Percutaneous absorption of benzophenone-3, a common component of topical sunscreens. Clin Exp Dermatol 27: 691-694, 2002.

63. Schlecht C, Klammer H, Jarry $\mathrm{H}$ and Wuttke W: Effects of estradiol benzophenone- 2 and benzophenone- 3 on the expression pattern of the estrogen receptors (ER) alpha and beta, the estrogen receptor-related receptor 1 (ERR1) and the aryl-hydrocarbon receptor $(\mathrm{AhR})$ in adult ovariectomized rats. Toxicology 205: 123-130, 2004.

64. Schlimpf M, Cotton B, Conscience M, Haller V, Steimann B and Liechtensteiger W: In vitro and in vivo estrogenicity of UV screens. Environ Health Perspect 109: 239-244, 2001.

65. Katiyar SK: Silymarin and skin cancer prevention: antiinflammatory, antioxidant and immunomodulatory effects (Review). Int J Oncol 26: 169-176, 2005. 
66. Seidlova-Wuttke D, Becker T, Christoffel V, Jarry H and Wuttke W: Silymarin is a selective estrogen receptor beta (ER-beta) agonist and has estrogenic effects in the metaphysis of the femur but no antiestrogenic effects in the uterus of ovariectomized (ovx) rats. J Steroid Biochem Mol Biol 86: 179-188, 2003.

67. Viggaard AM, Hnida C, Breinholt V and Larsen JC: Screening of selected pesticides for inhibition of CYP19 aromatase activity in vitro. Toxicol In Vitro 14: 227-234, 2000.

68. Kang IH, Kim HS, Shin JH, Kim TS, Moon HJ, Kim IY, Choi KS, Kil KS, Park YI, Dong MS and Han SY: Comparison of antiandrogenic activity of flutamide, vinclozolin, procymidone, linuron, and p,p'-DDE in rodent 10-day Hershberger assay. Toxicology 199: 145-159, 2004.
69. Kennel PF, Pallen CT and Bars RG: Evaluation of the rodent Hershberger assay using three reference endocrine disrupters (androgen and antiandrogens). Reprod Toxicol 18: 63-73, 2004.

70. Radice S, Fumagalli R, Chiesura E, Ferraris M, Frigerio S and Marabini L: Estrogenic activity of procymidone in rainbow trout (Oncorhynchus mykiss) hepatocytes: a possible mechanism of action. Chem Biol Interact 147: 185-193, 2004.

71. Rosen MB, Wilson VS, Schmid JE and Gray LE: Gene expression analysis in the ventral prostate of rats exposed to vinclozolin or procymidone. Reprod Toxicol 19: 367-379, 2005. 